\title{
Divided they stand: \\ Hollywood unions in the information age
}

\author{
Catherine McKercher \\ Vincent Mosco
}

Catherine McKercher is Associate Professor in the School of Journalism and Communication at Carleton University in Ottawa, Ontario, Canada.

Vincent Mosco is Canada Research Chair and Professor of Sociology at Queen's University in Kingston, Ontario, Canada.

\begin{abstract}
In an effort to increase labour power, trade unions representing communications and creative workers in North America have pursued a form of convergence, merging with each other and restructuring themselves along similar lines to their employers. This paper examines the issues surrounding labour convergence by taking up the failed merger between the Screen Actors Guild and the American Federation of Television and Radio Artists. It finds that, although the leaders of both unions supported the merger, the particular characteristics of the unions, including their culture, sense of craft identity and the lived experience of members, derailed the effort.
\end{abstract}

Research has demonstrated the importance of information and communication labour in the modern economy (Dyer-Witheford, 1999; Huws, 2003; Terranova, 2004). In an era characterised by declining trade union penetration, increasing corporate concentration, and the rise of global conglomerates that feed into - and are fed by - the spread of new communication and information technologies, North American knowledge workers have begun to explore new ways to increase the power of labour. This is especially the case in the communication sector, which provides the equipment that makes globalisation possible and the production and distribution of the ideas that make it work.

One approach is to pursue trade union mergers, designed strategically to restructure labour unions along much the same lines as the corporations that employ their members. Convergent unions like the Communications Workers of America (CWA) or the Communications, Energy and Paperworkers Union of Canada (CEP) bring together workers in what were once independent industries - newspapers, telecommunications, sound recording, broadcasting - but are now part of cross-media conglomerates. These unions also recognise that it's not just the boundaries between employers that have become less distinct; the boundaries between what were once distinct forms of work have also been blurred through the spread of digital technology. Labour convergence, therefore, is seen as an appropriate response to technological and corporate convergence (Bahr, 1998; McKercher, 2002; Swift, 2003). A second approach is to create 
non-traditional worker organisations, which draw into the labour movement people who cannot or will not join a traditional trade union. Such groups provide a range of services and supports for workers, their families or their communities but do not engage in collective bargaining. In North America, they are particularly prominent in the high-technology area (Kline, Dyer-Witheford and de Peuter, 2003; Stone, 2004; Van Jaarsveld, 2004 ).

This paper focuses on the issue of trade union convergence and specifically takes up this question: why would two unions facing an increasingly concentrated set of employers in the film and media industries decide not to merge? To answer this question, we draw on interviews with key participants and access to primary documentation to provide a detailed case study of the failed merger between the Screen Actors Guild (SAG) and the American Federation of Television and Radio Artists (AFTRA). The case is instructive for a variety of reasons. First, there is considerable research on the value of merger or convergence among trade unions, including in the communication and information industries (Batstone, 1984; Katz, 1997; Stone, 2004). It is important to examine through a detailed case study why such convergence may not be attractive to workers. Second, whilst unions are often viewed as bureaucratic institutions which make merger decisions based largely on the basis of a cost-benefit analysis (Chaison, 1986), this case vividly demonstrates that unions are also political institutions with at least formal democratic procedures that may significantly influence decisions about mergers. Specifically, while a merger might help SAG and AFTRA deal with media conglomerates, it might also mean that members would have to give up some of their influence over union decisions simply because the union has grown larger. Trade unions are also cultural institutions and the distinctive cultures associated with a self-consciously guild-oriented group of film workers (SAG) and a union-oriented organisation of workers who come out of a broadcasting tradition (AFTRA) also matter. Finally, the story of these two unions provides important lessons for those who would see a natural path to unity among knowledge and cultural workers (Terranova, 2004). Unity is not a given simply because workers produce the same product, i.e., digital content. If a merger cannot succeed in a highly concentrated industry between two unions that share a substantial portion of their membership, then perhaps the road to unity among workers in the network society may not be as clear as some would contend. With that said, our conclusions, based on one case study, cannot be definitive. However, they do raise questions that need to be considered in knowledge worker theory, research on the cultural industry workforce and studies of union mergers generally.

Those who support trade union convergence argue that it stands to benefit the labour movement, though it is not without problems (Swift, 2003). It is difficult, for example, to see what a news reporter has in common with a telephone operator, yet both could theoretically be accommodated by a single, amalgamated communication workers' union. Workers in the converging communications industries are increasingly involved in knowledge labour that requires similar sets of skills and training. And while specific differences among jobs exist, these are eroding as knowledge workers go through similar processes of deskilling and reskilling, and often deskilling again, and face similar challenges such as the outsourcing of their work (Mosco, 2005). Convergence enables previously independent unions to pool resources to concentrate on different struggles as they arise. It was vital 
in the 2005 fight by the Canadian Media Guild against the Canadian national public broadcaster, the Canadian Broadcasting Corporation (CBC), which locked out its workers for nearly two months in a failed effort to gain the unlimited right to hire temporary workers. The Canadian Media Guild is a branch of the Washington-based Communications Workers of America (CWA), a cross-border form of convergent unionism, and, following a bargaining unit consolidation ordered by the Canadian labour board, its $\mathrm{CBC}$ unit contains both on-air and technical employees. During the lockout at $\mathrm{CBC}$, journalists and technicians came together as never before. Their convergent union marshalled resources and talent to mobilise a degree of national support that surprised $\mathrm{CBC}$ management and many analysts. With the financial backing of the CWA, workers could afford to stay out longer. In addition to paying for half the strike pay and all the supplementary health benefits of locked-out workers, the CWA used its international networks to mobilise a pressure campaign that directed messages from media workers throughout the world to $\mathrm{CBC}$ management and the Canadian federal government. It also organised demonstrations at Canadian embassies in Washington, London and other power centres.

Convergence permits unions to speak with a voice that spans entire industries to get at the heart of central policy issues, as White concludes in a report for the Canadian Centre for Policy Alternatives on 'Losing Canadian Culture: The Danger of Foreign Ownership of Telecom' (White, 2005). Convergence also allows unions to work cooperatively as never before. In the United States the AFL-CIO recently threw its support behind a form of convergent unionism in the cultural sector by setting up an industry co-ordinating committee made up of ten unions covering the arts, entertainment, media and telecommunications industries. The committee's goal is to build labour power in industries that have been rocked by corporate concentration and technological change. It is worth noting that this action is also a response to the largest defection in the history of the federation, which occurred in 2005 when unions representing six million workers chose to leave and join the new Change to Win labour federation. Convergence, therefore, may also be a response to the failure of an organisation to maintain its membership.

While labour convergence has had its successes, there have been failures too. This paper tells the story of an unsuccessful attempt at creating a converged union of cultural workers in Hollywood, the heart of the US entertainment industry and still - despite challenges from Bollywood and other production centres - the film capital of the world. Unification has long been on the agenda of both the Screen Actors Guild (SAG) and the American Federation of Television and Radio Artists (AFTRA). In 1998, the two finally struck a deal and sent it to members for ratification. AFTRA's members endorsed it; SAG's did not. Five years later they tried again, with a new and different merger agreement. Again, AFTRA's members said yes, this time by a larger margin. So did a majority of SAG members. However, because the SAG vote fell short of the 60 per cent threshold required by both unions' constitutions for ratification, the merger was defeated. Says Mathis L. Dunn Jr., the Assistant National Executive Director of AFTRA, 'Had we been playing horse shoes or hand grenades, it would have been good enough. But that's not the case' (interview with the authors, February 2006). 
Despite majority support in both unions for the idea of unity, achieving labour convergence is no easy task. Chaison (1986) argues that trade union mergers occur when the incentives to unite outweigh the drawbacks of uniting. In this case, the incentives were clear: a merger would have put the unions in a stronger position to deal with the challenges of new technology and of an increasingly concentrated media industry. It would have eliminated the need for film, television and commercial actors to pay dues to two unions. It would also have streamlined the bureaucracy and ended the potential for employers to play one union off against the other. But trade union mergers are not simply a matter of calculating benefits and drawbacks (McKercher, 2002). Unions are political institutions, with their own governing and dues structures, bureaucracies, histories and, especially, their own cultures. Unlike the corporate mergers that have transformed the communications sector in North America in recent decades, labour union mergers require the approval of the full range of players in each potential partner: the elected leadership, the staff who have day-to-day contact with the membership, and the rank and file members. The fact that potential merger partners often have a shared history of competition and conflict as well as co-operation complicates matters for trade unions. As a result, mergers between labour unions are often more like the unification of rival states than they are like corporate mergers.

This paper shows that in the case of SAG and AFTRA, the particular characteristics of the unions, including their history, culture, sense of craft identity and the lived experience of members, derailed the unity effort. We conclude that the failure to merge has had consequences for how Hollywood's cultural workers deal with a range of issues, from new technology to global production.

\section{A tale of two unions}

If ever a compelling argument could be made for a union merger, it is the case of the Screen Actors Guild and AFTRA. These unions represent workers in the same industry, doing the same work, often under identical contracts. Between them, they represent the elite of creative workers in the United States. While AFTRA covers a broader range of workers - sound recording artists, radio and television journalists, performers in soap operas, talk shows, reality shows and game shows - film, television and commercial actors are the core constituency of both unions. Roughly 44,000 actors belong to both unions, which means 40 per cent of SAG's 120,000 members belong to AFTRA, and 60 per cent of AFTRA's 70,000 members belong to SAG. Since the early 1980s, under an agreement optimistically called 'Phase One of Merger', they have bargained jointly on their major national contracts with employers in the advertising and entertainment industries.

These unions did not start out as overlapping entities. Originally, they represented distinct groups of workers in distinctly different industries, working on opposite coasts of the United States. What pushed them together was a combination of new technologies and corporate concentration, a combination that continues to blur the lines that separate them today.

1 Phase Two was to be the creation of a new governing structure. Phase Three would have brought together the unions' health and pension funds (Prindle, p. 138). 
The Screen Actors Guild was founded in Los Angeles in $1933^{2}$. Right from the beginning, SAG was different from a standard trade union. To get around the possibility of individual members being held financially liable for collective action - a quirk of US. law that would change with the New Deal - it was set up as a corporation (Prindle 1988:22). This meant that SAG was a centralised organisation, run by a board of directors that would be elected by the full membership and would serve without salary. Voting membership in the union was limited to working actors. One of the unusual features in SAG's constitution was a requirement that strike votes had to be approved by a margin of 75 per cent. This bylaw continues to be in effect today (Constitution, 2003).

The American Federation of Radio Artists (AFRA) was founded in 1937 in New York, home of the US radio industry. AFRA's constitution vested power in local bodies, which elected their own boards and chose representatives to the national board. In this respect, it was much more like a traditional North American trade union than SAG. Both unions belonged to the Associated Actors and Artistes of America (AAAA), the American Federation of Labor's umbrella organisation for performers' unions. Performance was the common denominator of the two unions, but their jurisdictions were clearly and sharply delineated. Performing on radio was AFRA work ${ }^{3}$; acting before the cameras for later projection on a screen was SAG work. Actors who wanted to perform on both radio and film had to join both unions, and many $\operatorname{did}^{4}$.

When the radio networks expanded into new technology - television - the neat divisions began to break down. AFRA saw television as an extension of radio, and in terms of corporate ownership, the geographical location of the industry, and the way shows were produced and broadcast, that was certainly the case. It found allies in other New York-based performers' unions - representing theatre actors, singers, variety artists and musicians - who formed the Television Authority (TVA) and joined with AFRA in an effort to co-ordinate labour's response to the new technology. But television also meant projecting moving images on a screen, and therefore it held the potential for showing filmed programs. Film work was SAG work.

As television burst into North American homes after the end of the Second World War, the two unions wrangled over jurisdiction. In 1950, the AAAA awarded jurisdiction over television to AFRA (Prindle 1998, p76). SAG fought back, appealing to the federal labour regulator for certification elections to allow performers to decide for themselves which union should represent them. SAG won all but one of these elections and in 1952 AAAA gave up its attempt to create one big television union. SAG won the right to represent actors in filmed television programs. AFRA was given jurisdiction over live television. It merged with TVA and changed its name to AFTRA to reflect its expanded jurisdiction.

2 It was not the first union in Hollywood - the Screen Writers Guild appeared a few months earlier - nor was it the first to attempt to organise film actors. Actors Equity, the New York-based theatrical workers union, ran an unsuccessful recognition strike in 1929 ('The history of SAG', www.sag.org).

3 Radio was live work. In 1941 AFRA asserted jurisdiction over radio transcriptions, or recorded performances that could be broadcast later.

4 Indeed, Eddie Cantor, SAG's president from 1933 to 1935, became the first national president of AFRA two years later. Cantor began his career in vaudeville and starred on Broadway, in motion pictures and on radio. 
Over the next three decades, this division began to break down. The television business migrated west, from AFTRA's New York base to SAG's home ground in Los Angeles. Evolving technologies like videotape - which allowed for productions that were neither live nor on film - created confusion over jurisdiction. Television's ability to reuse material by showing theatrical films or broadcasting reruns of programs launched the unions on long and costly fights for what are called 'residual payments' for members. Meanwhile, actors complained about having to pay dues to two unions for doing essentially the same work. Writes Prindle, 'Periodically, the notion of eliminating the tangle of jurisdiction by merging all screen actors into one union would gain favor. SAG and AFTRA would consult about it and hire a professional researcher to do a study, there would be a good deal of argument back and forth, and after a while the impulse would peter out ' (Prindle 1998:77).

By the early 1980s, however, the talk had become much more purposeful. Merger discussions were promoted in large part by the introduction of cable television and the videocassette recorder, which threatened both the movie theatre business and conventional network television and put the residuals question back on the table. SAG still had jurisdiction over film and AFTRA over live performance and over tape. But these distinctions became less and less significant, and there were instances when a producer's decision to change studios - moving a television series from a facility that shot on film to one that shot on videotape, for example - meant changing unions (Prindle 1998:125). Because the unions had separate contracts, producers could use one against the other.

In 1981, the unions took a significant step toward uniting by signing the Phase One of Merger agreement that allowed them to jointly negotiate and ratify all major film and television contracts. Phase Two of Merger - bringing together governance of the two unions - never appeared. Instead, it became the victim of an internal struggle at SAG.

Not only does SAG have an unusual structure for a North American trade union, it also has an unusual political history. This is a union, after all, whose past presidents include the arch-conservative Charlton Heston and the radical Ed Asner - not to mention Ronald Reagan, the only trade union president ever to serve as president of the United States. From its earliest days, SAG has had both progressive and conservative elements. Indeed, the decision to call itself a 'guild' reflected the fact that many of the more conservative founding members felt uncomfortable about joining a union ${ }^{5}$. For its first four decades, conservatives dominated the SAG board, though the struggle between progressive and conservative actors provided a 'constant but muted' undercurrent in SAG politics (Prindle 1998:8).

The split between left and right is not the only fault-line in the union, however. There have also been tensions between the Hollywood, New York and regional divi-

$5 \quad$ The use of the word Guild was a popular choice among cultural workers in the US. It harked back to the artisans' associations of the mediaeval era, rather than to the factory-based trade union movements of the 19th and early 20th centuries. A guild could be seen as a professional association, and the name suggested exclusivity. In choosing the title of their organisation, the actors took their cue from the Screen Writers Guild. A few years later, the directors chose the name Screen Directors Guild, keeping the designation when they later changed their name to the Directors Guild of America. The union representing US newspaper journalists made the same choice, naming their organisation the American Newspaper Guild. Within a few years, however, it became a fully-fledged industrial union, seeking to represent a broad range of workers in the newspaper industry. 
sions, and between people who want to make their living as actors and people who see acting as a side line (and SAG membership as a status symbol). In addition, the income structure of SAG members is wildly skewed. Elite members earn millions of dollars per film, while the majority struggle to make ends meet. At any one time more than 80 per cent of SAG members are unemployed.

Since the 1980s, SAG has developed a de facto party system, an extremely rare feature in North American trade unions ${ }^{6}$. It is not a formal or institutionalised party system, in that the names (and at times the composition) of the parties change depending on the issue grabbing their attention, or on the views of the caucus of members promoting or contesting a particular issue. Competing slates of candidates for national office have become a regular feature in SAG elections. And this has had an enormous impact on attempts to merge with AFTRA.

In 1980 a group known as the Caucus of Artists for Merger, upset with the leaders of both unions and angry over what they saw as a botched strike that year, set out to gain power and influence on both the SAG and AFTRA governing structures, hoping to use that platform to bring about a merger. They won control of AFTRA's Los Angeles local the next spring, persuaded the well-known television actor Ed Asner to run for president of SAG a few months later, and in that year's election took control of the SAG board. Their hopes for a speedy merger were derailed by the creation of a conservative coalition, Actors Working for an Actor's Guild, whose members objected to Asner's radicalism in particular, and to the direction in which SAG was heading in general. The two factions tore at each other for much of the decade, ultimately sidelining the AFTRA merger talks in $1988^{7}$.

In the early 1990s, the unions decided to try again, going at things more slowly but also more steadily. Finally, in 1998, they made a deal. The agreement called for a full merger of the two unions into a new bod, to be called SAG/AFTRA, whose structure would reflect the traditions of both unions. It would have a strong national board of directors (a SAG feature) and 30 semi-autonomous locals (an AFTRA feature). The new union would have a new dues structure, but the two unions' health and pension plans would remain separate (Robb, 1999a). In promoting the merger to their members, the leaders of SAG and AFTRA argued that the merger would end jurisdictional disputes between the two unions, including a looming battle with the media conglomerates over revenues from high-definition television. It would also streamline operations and give the union more power at the bargaining table.

The merger agreement provoked a strong and vigorous reaction under the banner of a group called Save SAG. This largely conservative opposition group, a faction of a broader coalition known as the Performers Alliance, dismissed the prospect of a jurisdictional dispute as a scare tactic. The group also objected to the idea that dues would increase after the merger, and questioned the decision on health and pension plans. But

6 Another communications union, the International Typographical Union which represented printers, was the only other North American trade union with an institutionalised two-party system (See Lipset et al., 1956).

7 The SAG-AFTRA merger effort was knocked off the agenda by a vicious fight over a tangentially related merger between SAG and the Screen Extras Guild, which was to be a prelude to the larger merger with AFTRA. That deal was rejected by the SAG membership twice, the second time more decisively than the first (Prindle). 
perhaps the biggest success of the Performers Alliance was in convincing SAG members to embrace a narrow, craft-based view of trade unionism - to choose the 'purity of an actors' union rather than merging into a union with broadcasters and musicians' (Cooper, 2001).

Ballots went out to members in November 1998, with polls closing in January 1999. Both unions' constitutions require a merger vote to pass by a margin of 60 per cent. When the votes were tallied, 67.6 per cent of AFTRA voters supported the merger but only 46.5 per cent of SAG members voted for it (Kiefer, 2003; Robb, 1999).

Soon after, SAG went through another period of political turmoil. Its pro-merger president, Richard Masur, was replaced by the conservative William Daniels, who promised to get tough with the employers and presided over a divisive and combative two-year term that included the longest strike in the union's history, the six-month SAG/AFTRA commercials strike in 2000. Assessments a year later suggested that SAG's hard-line approach prolonged the dispute unnecessarily (Cooper, 2001). Daniels decided not to seek re-election in 2001, throwing his support to Valerie Harper. She lost the election to Melissa Gilbert, but the result was nullified because of balloting irregularities. Gilbert won the rerun election. A moderate, Gilbert headed a coalition known as Restore Respect, whose platform included support for a merger with AFTRA. Negotiations were on again, and in 2003 they resulted in a new agreement.

This deal, based on a set of principles drawn up by a joint committee of the two unions, tried to avoid some of the stumbling blocks that tripped up the previous merger. To recognise that SAG members didn't want to lose their identity or their traditions, the deal proposed an affiliation rather than a full merger. The new organisation would be called the Alliance of International Media Artists. It would have three autonomous, selfgoverning affiliates: SAG, covering actors; AFTRA, covering broadcasters; and the American Federation of Recording Artists, covering singers and recording artists. Each affiliate would have its own board and officers. Again, the health and pension plans would remain separate, but the trustees of both would look into the possibility of consolidating them (Connell, 2003; Kiefer, 2003).

In announcing the details of its consolidation plan to members, AFTRA's Magazine pointed out that one of the 'common perceptions' in the 1999 merger result was that there was 'no imminent or compelling need to take action ' (Winter 2003:5). This time, it argued, things were different:

'The emergence of digital production has rapidly escalated the jurisdictional conflict.

This serves to: 1. Drive down terms and conditions for performers. 2. Divert resources from critical union initiatives ' (Winter 2003:5).

If new technology was a compelling factor in favour of a merger, so was industry consolidation. The same issue of the magazine summarised the changes: the number of major employers of performers and broadcasters had declined from 26 in 1985 to six, five of them in the television and motion picture industry; eight studios controlled 88 per cent of all domestic theatrical production and distribution; five record companies controlled 84 per cent of the recording industry; cable revenues increased from $\$ 5$ billion in 1990 to $\$ 35$ billion in 2002, and the cable market was controlled by five companies; two cable system owners, AT\&T and Time Warner, accounted for 40 
per cent of all cable households; two companies owned more than 1,400 radio stations and one, Clear Channel, was comprised of what used to be 70 separate companies. The magazine put it this way:

'While AFTRA and SAG have been thinking about consolidating, our employers have actually done it. The industry already has consolidated' (Winter 2003:4).

As with the previous merger vote, the campaign was heated. A reinvigorated Save SAG argued that the plan would result in a loss of direct fiscal control over SAG's budget, and that the actors' union would be reduced to a 'glorified committee' of a larger union (Kiefer, 2003). In an interview with the New York Times, former SAG president Daniels brusquely dismissed the idea that a merger would make SAG stronger:

'AFTRA is a crummy little union, and they're undercutting our contracts, so we should

join them? To us it's a very, very bad deal' (quoted by Connell, 2003).

The opponents also made much of the uncertainty about the future of the pension and health plans (Connell, 2003) - a tactic that frustrated members of the committee that negotiated the deal. Matt Kimbrough, AFTRA's National Recording Secretary, explains that because the plans were created and governed separately from the unions, 'you couldn't even begin the process of merging the plans until you actually merged the unions.' (interview with the authors, 2006).

But this meant that merger advocates could not offer clear answers to questions about what the merger would mean for actors' pensions, a situation that opponents to the merger used to fan actors' fears about the future.

The voting took place in the summer of 2003. AFTRA members overwhelmingly endorsed the merger, with 75.8 per cent of votes in favour. At SAG, the deal lost by a hair. The merger needed 60 per cent of votes to pass; it got 57.8 per cent (Kiefer, 2003).

Pamm Fair, the Deputy National Executive Director of SAG, says post-election polling of SAG members found that the vast majority wanted a merger; 'they just didn't like that plan' They also objected to the idea that the new union would have a different name. 'Our people said, "What, are you crazy? We have worldwide branding with the name we have now. Why would you think about changing it?" The pension and health care issue also resonated with members, especially since SAG's plans are comparatively healthier - and less expensive for members - than AFTRA's.' (interview with the authors, February 2006).

Kimbrough, who is also a member of SAG, says that the opponents of the merger came up with a short and simple slogan to sink the deal: 'If you don't know, vote no'. It worked brilliantly.

'The members were sold on the notion that if you vote no now, there's going to be another vote later, when there was never any intention from the people trying to defeat it that there should be a merger agreement.' (interview with the authors, 2006)

He agreed that the name of the new organisation was an issue, as it had been in 1998. Hollywood is, after all, SAG's town, and the SAG name is known throughout the world. Kimbrough says that if two sides had simply agreed to call the new union SAG, the merger might have passed. But that would have been unacceptable to AFTRA, since it would imply an absorption by another union. Leslie Simon, Director of Legislative and Public Affairs for AFTRA's Los Angeles local, adds another reason for the failed merger: 
'Fundamentally, there was a lack of recognition of how the industry has changed, of why it is that two unions are no longer acceptable and no longer can do the job for actors.' (interview with the authors, 2006)

Finally, as in 1999, the pro-merger side was unable to overcome the opponents' appeal to craft solidarity: the notion that actors are artists who shouldn't be co-mingled in a union with broadcast journalists or musicians. Ron Morgan, President of AFTRA's Los Angeles local and a SAG member as well, says this argument was strictly an emotional one. But when all was said and done it 'resonated stronger than anything else' (interview with the authors, 2006).

\section{Divided they stand}

After the merger was defeated, each union had to chart a new course based on maintaining the status quo of two unions rather than the synergy of one. SAG elected a new president, Alan Rosenberg, whose Membership First coalition currently holds a majority on the national board (Armbrust, 2005). Rosenberg opposed the AFTRA merger; instead, he would prefer to see all actors come to SAG. Rosenberg is a political liberal who was an anti-war activist during the Vietnam War, has worked in the civil rights movement and is an advocate for social justice. He pledges - as did the conservative Daniels - to get tough with the employers. He told the Los Angeles Times:

'Until now, the studios have looked at how fractured we are as a union and haven't taken us very seriously. So my philosophy is that we have to take an adversarial position and stand strong and never leave the negotiating table until we make progress and prevail.' (quoted in Goldstein, 2005)

Since taking office, Rosenberg has presided over the firing of the union's executive director, who had been a key player in negotiating the failed AFTRA merger. He has also begun to work more closely with two other Hollywood unions that have fought their own internal battles: the Writers Guild of America and the Directors Guild of America. 'If we could present a united front with the WGA and the DGA, we'd be a lot stronger...Since late 2005, for example, the writers' and actors' guilds have been campaigning together for tougher rules on product placement, which the unions see as "stealth advertising"'. (ibid)

Following the failed merger, AFTRA undertook a major restructuring. It plans to move its national headquarters from New York to Los Angeles, home of its largest local. It has also embarked on a series of structural changes - reducing the size of its executive board, for example - that are aimed at cutting costs, reducing its deficit and increasing its revenue (AFTRA Magazine 2004-05; Horwitch, 2005).

Both unions continue to work together on contract negotiations. This included successful negotiations in 2005 on a contract covering voiceover actors featured in video games, an area that is not included in the 1981 agreement on joint bargaining. Both are also active in the formation of the AFL-CIO's new industry co-ordinating committee, which covers unions in the arts, entertainment, media and telecommunications industries (AFL-CIO 2005; Eggerton 2005). The federation says that the council's goal is to build more power for workers by undertaking collaborative initiatives in four areas: organising, collective bargaining, contract standards and public policy. Pamm Fair of SAG, 
who works on policy and strategic planning, says she hopes the committee will serve as an arbitrator for jurisdictional problems that may come along. Kimbrough says that AFTRA is hoping to play a pivotal role in the creation of the council and is keen to see it succeed. But he is not certain about SAG's commitment to the idea. 'Right now I think that in a lot of these questions, the Guild is a wild card', he says.

Clearly, the unions have shown that it is possible to continue to work closely together despite the disappointment of the 2003 merger vote. But it is also clear that the failure to unite has created problems for both unions. Perhaps the most significant is the fact that they now find themselves competing over new digital technologies. A host of new devices and media have arrived since the last merger vote - podcasts, satellite radio, ipods with video screens, interactive blogs, cell phones with video and so on. These devices have all but obliterated the lines between various types of performance, and pose the most serious challenge yet to jurisdictional divisions. In January 2006, AFTRA president John Connolly set out his union's stance on digital technology, recording a podcast to do so:

'This message [is] an acknowledgement of AFTRA's readiness and resolve to organise the digital markets of the 21st century - proof positive that AFTRA is the future in media.' (AFTRA, 4 January 2006)

Shortly after that, the union announced that two new prime-time series shot in digital format were under AFTRA contract (Miller 2006). Because SAG also claims that its contracts cover digital production, this means the two unions are now competing for digital work. Both are aware that competition tends to benefit the employers rather than the workers. As AFTRA's Kimbrough puts it,

'The only way a union competes with another union for a job is to offer the producers a better deal. That's a hard truth and it's not good for the members'. But each union feels it has no choice.' (interview with the authors, 2006)

Another area where the failure to merge is likely to have consequences is in the campaign against what Hollywood likes to call 'runaway production' - the production of films and television shows in lower-cost, incentive-rich, non-Hollywood locales like Canada. SAG's approach has been to build a series of coalitions to address the issue in a number of ways. With the Directors Guild, it commissioned a ground-breaking economic analysis of the problem. It then helped the Directors Guild create a 19-member coalition known as the Runaway Production Alliance to fight for federal and state legislation to subsidise domestic film production. The alliance includes not just trade unions, but also professional and trade organisations, as well as groups representing marketers, distributors, promoters, talent agents and musicians - anyone in Hollywood with a stake in the issue. SAG has also extended its jurisdiction beyond the US border through its Global Rule One campaign, which says that SAG members can only work for producers who sign SAG agreements, regardless of where they film. AFTRA has been very much onside in this campaign, participating in the Runaway Production Alliance and issuing public statements in support of Global Rule One. Though they may be effective, informal coalitions are, however, inherently unstable. They work only as long as they meet the self-interest of the individual members. Kimbrough says that AFTRA is considering whether to continue the lobbying effort against runaway production at the same level because it is not that sure that it is worth the time, money and effort. He explains, 
'We've spent a considerable amount of energy and capital in support of these bills, and that has gravitated to the benefit largely of the Screen Actors Guild. There has not been a terrific amount of growth in AFTRA work as a result of these bills.' (interview with the authors, 2006)

Meanwhile, SAG is thinking about ramping up its fight. Its board voted in late 2005 to support a coalition of other unions that have been exploring the idea of launching a complaint with the US trade representative office against Canadian film subsidies. This would seek to have Canada's subsidies declared a violation of trade agreements. Fair says SAG has not committed any funding to the initiative, but is helping with legal research. AFTRA, by contrast, has no interest in the trade case. Says Kimberley, 'Politically we have voted it down every time it comes up in our boardroom. We regard it as counter-productive.' (interview with the authors, 2006)

Ron Morgan, the president of AFTRA's Los Angeles local, says that focusing too much attention on runaway production misses the larger issue: confronting Hollywood unions. 'The real runaway production issue, to me, is not that the work is going to Canada, but that it's going non-union. That's runaway production as far as I'm concerned.' (interview with the authors, 2006)

\section{Conclusion: going it alone in the age of convergence}

If Morgan is right, the solution to the problem of the increase in non-union work is to capture - or in some cases, recapture - the work. And this is where labour convergence may play a critical role. We began this paper by suggesting that the twin challenges of new technology and corporate concentration are prompting worker organisations to explore new ways of increasing labour power. Few places offer as vivid an example of both phenomena as Hollywood. Between them, corporate consolidation and technological convergence have undermined existing union jurisdiction, opened up new areas of non-unionised work and tipped the balance between labour and management sharply in favour of the employers. A merger between SAG and AFTRA would have helped the members of both unions. It would have ended the competition for work between SAG and AFTRA, a competition that chiefly benefits the employers. Individual actors would pay only one set of dues, not two. The organisation resulting from the merger would be simultaneously more united and, with AFTRA's non-acting membership, more diverse. In short, the new union would have been more like a convergent union than a craft union. The kind of craft-centred toughness displayed by the current leadership of SAG can be effective in protecting a position, especially in the short term.

As this paper has shown, however, by rejecting AFTRA - twice - the Guild has lost an opportunity to solidify its relationship with its closest ally. As a result, two unions that are each other's best colleague find themselves having to devote resources to competing with each other, all the while knowing that those resources might better be spent promoting their joint interests. For those opposed to the merger - a minority at SAG, but a large enough one to determine the outcome of the vote in 2003 - this is a small price to pay for retaining political and cultural independence. The current leadership of SAG believes its members will be better off because it is taking a tougher 
political stance against the industry and those in Washington who support the industry. Moreover, the status quo preserves the independent guild culture of SAG, a culture deeply rooted in the history of a labour organisation that has struggled with seeing itself as a trade union. All this questions the perceived commonalities among communication workers that purportedly make them easier to organise and mobilise.

At this point, neither side is talking about taking another run at a merger. Both are committed to working side-by-side on contract negotiations, and on the AFL-CIO's industry co-ordinating committee for the media and telecommunications sectors. In the longer term, shoring up their mutual relationship while building strong bridges to other cultural worker organisations, in Hollywood and beyond, may be critical to whether they thrive or merely survive.

\section{(C) Catherine McKercher and Vincent Mosco, 2006}

\section{REFERENCES}

AFL-CIO (2005), 'AFL-CIO Executive Council Announces Formation of First Industry Co-ordinating Committee Covering the Arts, Entertainment, Media and Telecommunications Industries', News Release, Washington, 6 Oct AFTRA (2004) 'AFTRA Board Approves Sweeping Overhaul of Union's Structure', News release posted on www.aftra.org 10 July. Accessed 16 March 2006 AFTRA (2003) 'AFTRA consolidation plan', AFTRA Magazine, Winter:3-5

AFTRA (2006) 'AFTRA introduces national president's message podcast on website', News release posted on www.AFTRA.org 4 Jan. Accessed 16 March 2006

AFTRA (2006) 'A Small Slice of AFTRA History', www.aftra.org. Accessed 16 March 2006

Armbrust, Roger (2005) 'SAG’s Christie Rebuts Rosenberg, Who's N.Y.-Bound', Backstage.com, 3 Nov. Accessed 16 March 2006

Bahr, Morton (1998) From the Telegraph to the Internet, Washington: National Press Books, Batstone, Eric (1984) Working Order: Workplace Industrial Relations over Two Decades, Oxford: Basil Blackwell

Chaison, Gary N. (1986) When Unions Merge, Lexington, Mass: Lexington Books Connell, Angel (2003) 'AFTRA/SAG's Failed Consolidation and its Impact on New England's Acting Community', New England Entertainment Digest, 29 July. Posted on www.jacneed.com. Accessed 16 March

Constitution and By-Laws (2003) Screen Actors Guild, July

Cooper, Marc, (2001) 'Residual Anger', The Nation, April 2. Posted on www.thenation.com. Accessed 16 March 2006

Dyer-Witheford, Nick (1999) Cyber-Marx: Cycles and Circuits of Struggle in High Technology Capitalism,Urbana and Chicago: University of Illinois Press

Eggerton, John, (2005) 'Unions consolidate to face merged media.' Broadcasting \& Cable, 11 Oct. Goldstein, Patrick, (2005) 'His Union Divided Cannot Stand' Los Angeles Times, 4 Oct. 2005:E1. Horwitch, Lauren (2005) 'AFTRA Tackles Finances', Backstage.com, 22 July 2005. Accessed 16 March 2006

Huws, Ursula (2003) The Making of a Cybertariat: Virtual Work in a Real World, New York: Monthly Review Press,

Katz, Harry C. (ed.) (1997) Telecommunications: Restructuring Work and Employment Relations Worldwide, Ithaca, NY: ILR Press

Kiefer, Peter (2003) 'SAG-AFTRA merger proposal shot down', The Hollywood Reporter.com, 2 July. Accessed 16 March 2006.

Kline, Stephen, Nick Dyer-Witheford and Greig de Peuter (2003), Digital Play: The Interaction of Technology, Culture and Marketing, Montreal: McGill-Queen's Press 
Lipset, Seymour M., Martin A. Trow and James S. Coleman (1956) Union Democracy: The Internal Politics of the International Typographical Union, Glencoe, Ill.: The Free Press

McKercher, Catherine (2002) Newsworkers Unite: Labor, Convergence and North American Newspapers, Lanham, Md.: Rowman and Littlefield

McNary, Dave (2005) 'SAG looks to law on runaway prod'n', Variety.com, 26 Oct. Accessed 16

March 2006

Miller, A.L. (2006) 'AFTRA, the Monkey on SAG Actors Backs.', Posted on SAG Watchdog blog, www.sagwatchdog.com, 18 Jan. Accessed 16 March 2006

Mosco, Vincent (2005) 'Here Today, Outsourced Tomorrow: Knowledge Workers in the Global Economy', Javnost/The Public 12 no. 2:39-56

'National Board Begins AFTRA Restructuring', AFTRA magazine, Fall/Winter 2004/2005:3-4

Prindle, David F (1988) The Politics of Glamour: Ideology and Democracy in the Screen Actors Guild, Madison: The University of Wisconsin Press

Robb, David (1999) 'SAG-AFTRA ballots due at 5 p.m.', The Hollywood Reporter, 25 Jan. Hollywoodreporter.com, accessed 16 March 2006

SAG (2006)'The History of SAG’ www.sag.org. Accessed 16 March 2006

'It's still two parts for actors', The Hollywood Reporter, 29 Jan. 1999. Posted on www.performersalliance.tv/archive/hr_Jan2899.html. Accessed 16 March 2006

Stone Katherine V.W (2004) From Widgets to Digits: Employment Regulation for the Changing Workplace, Cambridge: Cambridge University Press

Swift, J. (2003) Walking the Union Walk, Toronto: Between The Lines

Terranova, T. (2004) Network Culture: Politics for the Information Age, London: Pluto

van Jaarsveld, D. D. (2004) 'Collective Representation Among High-Tech Workers at Microsoft and Beyond: Lessons from WashTech/CWA', Industrial Relations 43, no. 2 (April):364-85.

White, J. (2005) 'Losing Canadian Culture: The Danger of Foreign Ownership of Telecom', Canadian Centre for Policy Alternatives: Trade and Investment Series, 31 October, Available at: $<$ http://www.policyalternatives.ca/documents/ National_Office_Pubs/2005/brief6_3_Losing_Canadian_Culture.pdf $>$.

\section{INTERVIEWS BY THE AUTHORS}

Mathis L. Dunn, Jr., Assistant National Executive Director, AFTRA; interim executive director of Los Angeles Local. Los Angeles, 6 Feb. 2006

Pamm Fair, Deputy National Executive Director, Policy and Strategic Planning, SAG. Los Angeles 3 Feb. 2006

Matt Kimbrough, AFTRA National Recording Secretary, Member of AFTRA National Executive Board and President's Strategy Cabinet. Also member of SAG. Los Angeles 6 Feb. 2006

Lise Lareau, National President, Canadian Media Guild, 2 March 2006

Ron Morgan, President of AFTRA Los Angeles Local; member of AFTRA national board. Also member of SAG. Los Angeles, 6 Feb. 2006

Leslie Simon, Director, Legislative and Public Affairs and Spanish Language Media Project, AFTRA Los Angeles local. Los Angeles, 6 Feb. 2006

\section{ACKNOWLEDGEMENTS}

The authors would like to acknowledge a grant from the Social Sciences and Humanities Research Council of Canada to support ongoing research on Trade Unions and Convergence in the Communication Industry. We also thank the Screen Actors Guild, the American Federation of Television and Radio Artists, and the Canadian Media Guild for agreeing to the interviews that provided vital information for this paper. 